Review Article

\title{
Conceptual Study of Asthi Pradoshaja Vikaras
}

\author{
Ranjith Kumar Shetty
}

Associate Professor, Dept. of Basic Principles, Sri Sri College of Ayurvedic Science and Research, Bengaluru, Karnataka, India. DOI: https://doi.org/10.24321/2394.6547.201907

I $\quad \begin{array}{lllll}\mathbf{N} & \mathbf{F} & \mathbf{O}\end{array}$

E-mail Id:

drranjithayu@gmail.com

Orcid Id:

https://orcid.org/0000-0002-5356-7807

How to cite this article:

Shetty RK. Conceptual Study of Asthi Pradoshaja

Vikaras. J Adv Res Ayur Yoga Unani Sidd Homeo

2019; 6(3\&4): 4-9.

Date of Submission: 2019-10-01

Date of Acceptance: 2019-12-20

\author{
$\begin{array}{llllllll}\mathbf{A} & \mathbf{B} & \mathbf{S} & \mathbf{T} & \mathbf{R} & \mathbf{A} & \mathbf{C} & \mathbf{T}\end{array}$
}

The Shareera is made up of Dosha, Dhatu and Mala. Among them Dhatu is meant for Dehadharana specifically by Asthi Dhatu. When this dhatu gets vitiated by doshas it leads to a specific condition known as Dhatu Pradoshaja Vikara. Among the Dhatu Pradoshaja Vikaras, Asthi Pradoshaja Vikara is one. Dalhana mentioned the reason behind explaining the Dhatu Pradosaja Vikara separately, these are 1. Chikitsa Vishesa Vijnanartha, 2. Sukha sadhyatvadi Karma Bodhartham Knowledge of these two is very much essential for a Vaidya. Chakrapani distinctly revealed that in some cases only Dosha Viparita Chikitsa will not bring complete relief to the patient. One should treat Dhatu also because of Ashraya Prabhava. Dhatu Pradoshaja Vikara is a condition in which the Dhatus are in vitiated state. Among the Dhatu Pradoshaja Vikaras, Asthi Pradoshaja Vikaras include Adhyasthi, Asthibheda, Asthishula etc. Acharya Charaka mentioned that Panchakarma, Ksheera, Sarpi \& Tikta Dravya Basti are the treatment modalities for Asthi Pradoshaja Vikaras.

Keywords: Dhatu Pradoshaja Vikara, Nidana-Lakshana-SampraptiChikitsa Asthi Pradoshaja Vikara

\section{Introduction}

Being an eternal science, 'Ayurveda', the 'science of human life', deals with physical, psychological as well as spiritual wellbeing of an individual. It covers all the spheres of human life. It is not merely a materialistic science, but a philosophical and factful truth, which our great ancestral sages, through their experience, logic and power of wisdom, had found true and proved it to the truth of time. To keep it in pace with advancing or so called modern age or scientific age is the present day task. To proceed with such an incredibly rewarding task, is not more a challenge but an exhaustive endeavour.

Human creatures have emerged as specialized species in the process of evolution. The study of human being includes both physiological \& pathological entities. Ancient seers of Ayurveda have classified the elements of the body under three fundamental components- Dosha, Dhatu and Mala.
These three entities are responsible for the maintenance of structural and functional integrity of the body. Among these basic elements Dhatus are especially meant for Dharana \& Poshana of Shareera. The equilibrium state of these Dhatus results in Arogya, where as any imbalance in it produces Vikara. Dhatu Pradoshaja Vikara is a condition in which the Dhatus are in vitiated state. In the present context the conceptual study on Asthi Pradoshaja Vikara is taken for better understanding as well as for clinical practice.

\section{Review of Literature \\ Definition}

When the Dhatus are vitiated extremely by the Doshas then it causes respective "Dhatu Pradoshaja Vikara" it may be Rasa Pradoshaja Vikara, Rakta Pradoshaja Vikara or Asthi Pradoshaja Vikara etc. ${ }^{1}$ Chikitsa Vishesa Vijnanartha (related to management of the diseases) and Sukha sadhyatvadi 
Karma Bodhartham (regarding prognosis) are the reason to explaining the Dhatu Pradoshaja Vikara separately by Dalhacharya. $^{2}$

\section{Asthi Pradoshaja Vikara ${ }^{3,4}$}

The Asthi Pradoshaja Vikara which are mentioned in different classics are tabulated below.

\begin{tabular}{|c|c|c|}
\hline Asthi Pradoshaja Vyadhi & Ca.Su & Su.Su \\
\hline Adhyasthi & + & + \\
\hline Adhidanta & + & + \\
\hline Dantabheda & + & - \\
\hline Dantashoola & + & - \\
\hline Asthibheda & + & - \\
\hline Asthishoola & + & + \\
\hline Vivarnata & + & - \\
\hline Kesa, Loma, Nakha, Smashru & + & - \\
\hline Dosha & - & + \\
\hline Kunakha & - & + \\
\hline
\end{tabular}

As per the Yogendranath Sen the Kesha, Loma and Smashru are Malas of the Asthi Dhatu. This is the reason to consider Keshadi Doshas as one among the Asthi Pradoshaja Vikara. ${ }^{5}$

\section{Nidana $^{6}$}

The Nidanas are:

- Ativyayama: excessive physical strain.

- Atisankshobha: It means abhighata i.e, any kind injury

- Ativigattana: It means excessive movements or separated or loosened or shaking.

- Vatalaahara and Vihara Sevana: Ruksha - SheetaLaghu Guna Pradhana Ahara Sevana, Alpa Matra Ahara Sevana, Mudga, Masoora, Vaartaaka, Kalinga, Harenuka etc., Ativyavaya, Atijagarana, Krodha, Bhaya, Vegadharana, Abhighata, Upavasa, Shoka, Plavana etc.

\section{Rupa}

- $\quad$ Adhyasthi: ${ }^{7}$ Adyasthi means Adhika Asthi i.e, additional bone or extra bone.

- Adhidanta: ${ }^{8}$ Adhidanta means Adhika Danta i.e, additional tooth or extra tooth.

- Dantabheda: ${ }^{9,10}$ It is a condition were cutting type of pain in Danta is seen and is called as Dantabheda.

- Dantashoola: ${ }^{11,12}$ There will be a severe or acute pain in the tooth is called as Dantashoola.

- Asthibheda: ${ }^{13}$ It is a condition in which Bhidhyamanasya Vyatha (cutting type or splitting type of pain) will be present in Asthi.

- Asthishoola: $:^{14}$ It is a condition in which severe or acute pain in Asthi like Shanka Sphutanavat.

- Asthitoda: ${ }^{15}$ It is a condition in which Vicchinna Shoola (pricking or breaking type of pain) will be present in Asthi.

- Vivarnata: These disorders are two in number. They are Shyavadanta and Krimidanta.

- Kesha, Loma and Smashru Vikaras: The Kesha, Loma and Smasru Vikaras are Indralupta, Ruhya, Khalitya and Palitya.

- Kunakha: ${ }^{16} \mathrm{~A}$ disease of the nails which is ugly in appearance. This condition is called as Kunakha.

\section{Samprapti ${ }^{17}$}

These excessive vitiated Dosha when lodges in Asthi Dhatu, the manifestation of Asthi Pradosaja Vikara takes place at various sites in the body according to Sthana Dusti or Khavaigunya, which is due the specific Nidana like Ativyayama, Atisankshobha, Ativighattana and Vatala Ahara-Vihara by the persons when they exposure to these for longer duration.

\section{Chikitsa}

According to Charaka Samhita, Asthyashrita Vyadhi are treated by Panchakarma, especially by Basti, which is prepared out of Ksheera, Sarpi and Tikta Dravyas. While commenting on Chikitsa Sutra Chakrapani opines that Tikta Ksheera Sarpi Basti is 'Hita' for Asthi Pradoshaja Vikara. ${ }^{18}$

\section{Discussion}

\section{Discussion on Definition}

When the Asthi gets vitiated extremely by the Vata Dosha along with other Doshas and changes its natural form and leads to a specific condition which is known as Asthi Pradoshaja Vikaras.

\section{Classification of Asthi Pradoshaja Vikara}

Depending upon involvement of different parts, the Asthi Pradoshaja Vikara can be classified into four types. They are;

- Asthi Pradoshaja Vikara due to involvement of Asthi. E.g; Adhyasthi, Asthishoola.

- Asthi Pradoshaja Vikara due to involvement of Danta. E.g; Dantashoola, Dantabheda.

- Asthi Pradoshaja Vikara due to involvement of Kesha, Smashru and Loma. E.g; Indralupta, Khalitya, Palitya

- Asthi Pradoshaja Vikara due to involvement of Nakha. E.g; Kunakha

\section{Discussion on Nidana}

The Nidanas which are mentioned for Asthi Pradoshaja Vikara can be classified as follows:

- Aharaja Nidana: Vatala Ahara

- Viharaja Nidana: Ativyayama, Ativighattana 


\section{- Manasika Nidana: Atisankshobha}

\section{Vatala Ahara and Vihara Sevana}

Over indulgence in Ruksha, Laghu and Alpa Matra Ahara aggravates Vata in the Shareera. The chief qualities of Vata Ruksha, Laghu, Sukshma etc. these are similar to each other. So it will lead to Vata vitiation. Viharas like Atichesta, Abhigata, etc cause the Vata vitiation. When the vitiated Vata gets lodges in Asthi, it leads to different disorders.

\section{Ativyayama}

Ativyayama means excessive Shareera Ayasajanaka Karma i.e., more than Ardhashakti Vyayama. When person performs the Ativyayama continuously it leads to the increase in Laghu, Ruksha, Sukshma, Teekshna Guna in the Shareera. Later it invariably leads to Vata vitiation. Because Vata have the same gunas like Ruksha, Laghu, Sukshma etc on the basis of Samanya Siddhanta. As per the contemporary science, excessive exercise causes the injury to the body like bone fracture, bone pain etc.

\section{Ativighattana}

Ativighattana means excessive movements or separation or injury. It directly affects the particular part of the body. It is considered as the Abhighataja Nidana. Here it directly affects the Asthi Dhatu initially later vitiation of Vata Dosha takes place due to Ashraya Ashrayee Bhava. Then it leads to different disorders like Asthibheda, Asthishoola etc. even in the contemporary science, it is mentioned that external injury is one of the main causative factor for the manifestation of bone disorders like osteoarthritis etc.

\section{Atisankshobha}

Atisankshobha means excessive Manasika Kshobha (mental stress or disturbance). When the person is under mental stress, then it will lead to increase in Rajoguna in the Shareera. As per the classics, Rajoguna is one among the Vata Guna. So it invariably increases the Vata Dosha in the Shareera. As per the contemporary science mental disturbance is the cause for all most all the disorders.

\section{Discussion on Rupa}

\section{Adhyasthi (Bone spur)}

It refers to additional bone or extra bone. It generally forms in response to pressure, rubbing, or stress that continues over a long period of time. It is usually smooth, but it can cause wear and tear or pain if it presses on the other bones or soft tissues. e.g.; calcaneal spur.

\section{Adhidanta (Hyperdontia)}

It refers to additional or extra teeth. Which appear in addition to the regular number of teeth and is mal-formed.

\section{Dantabheda and Dantashoola (Odontalgia)}

As per Ayurvedic classics these are two different disorders. Here patient suffers from different form of pain like cutting; pricking etc. This pain can often be aggravated somewhat by chewing or by hot or cold temperature.

\section{Asthibheda, Asthishoola and Asthitoda (Bone Pain)}

Details regarding each disorder are not available in any of the classics. The individual feels different forms of pain in the bone due to different disorders. In the contemporary science there are conditions characterized by bony pain which includes both acute and chronic. Chronic pain will be present in some disorders like Osteoarthritis; Paget's disease etc. Acute pain will be present in the fractures.

\section{Shyavadanta (Tooth Discoloration)}

The blackish or Kapila Varnata of the tooth is called as Shyava Danta. Tooth discoloration is caused by multiple local and systemic conditions. Extrinsic dental strains are caused by poor oral hygiene etc. Intrinsic dental strains are caused by dental materials (eg, tooth restorations), dental conditions and caries, trauma, infections, medications, nutritional deficiencies and genetic defects and hereditary diseases (eg, those affecting enamel and dentin development or maturation).

\section{Krimidanta (Dental Caries)}

In this condition Danta becomes Krishna Varnata, Chidrayukta, Sravayukta or sometimes with Shoola. Dental caries is a disease where bacterial processes damage hard tooth structure.

\section{Indralupta (Alopecia Areata)}

The hair loss all over the body or partial loss.

It can be correlated to alopecia areata or sometimes it is called as spot baldness, in which hair is lost from the localized area or all areas of the body, usually from the scalp.

\section{Khalitya (Alopecia Areatauniversalis)}

There is no chance for regrowth of hair in scalp.

\section{Palitya (Grey Hair)}

When the hair becomes Kapila Varna in the early age then it is called as Palitya. This condition can be correlated to the premature grey hair. Early or premature greying of hair is basically hereditary and other causes are stress, anxiety and malnutrition.

\section{Kunakha (Onychogyphosis)}

This is a condition in which Daha, Paka, Vedana and Asita Varnata will be present in the Nakha. This can be correlated to the onychogryphosis. 


\section{Discussion on Samprapti}

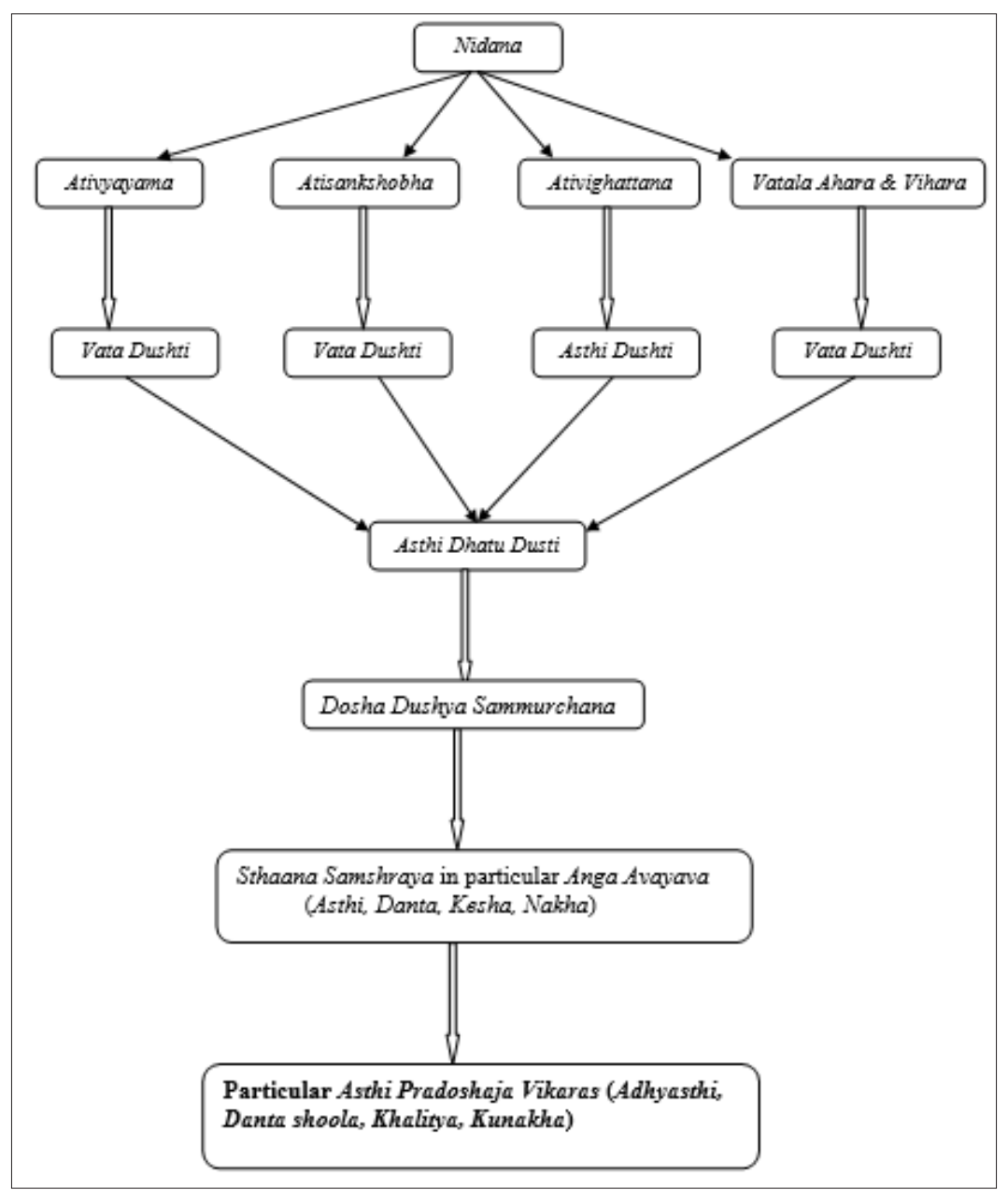

\section{Discussion on Sadhyaasadhyata}

\begin{tabular}{|c|c|c|c|}
\hline Vyadhis & Asadhya & Yapya & Kashta \\
\hline Dhaalana & + & - & - \\
\hline Bhanjanaka & + & - & - \\
\hline Shyavadanta & + & - & - \\
\hline Tridoshajakhalitya & + & - & - \\
\hline Tridoshajapalitya & + & - & - \\
\hline Dantashoola & + & + & - \\
\hline Indralupta & - & + & - \\
\hline Ekadoshajakhalitya & - & + & - \\
\hline Ekadoshajapalitya & - & - & + \\
\hline Adhyasthi & - & - & + \\
\hline Adhidanta & - & - & + \\
\hline Dantabheda & - & - & + \\
\hline Asthishoola & - & - & + \\
\hline Asthitoda & - & - & + \\
\hline Kunakha & - & & \\
\hline
\end{tabular}


Among the Asthi Pradoshaja Vikara Dhaalana, Bhanjanaka, Shyavadanta, Tridoshaja Khalitya, Tridoshaja Palitya and Dantashoola are considered as Asadhya Vyadhis because these are Tridoshaja Vyadhis and treatment modality in such cases are not satisfactory and prognosis is very poor. The diseases like Indralupta, Ekadoshaja Khalitya and Ekadoshaja Palitya are considered as Yapya Vyadhi because it requires long duration of treatment and sometimes it gets may cured but chances of reoccurrence are more. Other diseases like Adhyasthi, Adhidanta, Dantabheda, Asthishoola, Asthitoda and Kunaka are considered as Kashtasadhya Vyadhi because it requires both shaman Aoushadhi and Shastra Karma.

\section{Discussion on Treatment}

In Charaka Samhita the treatment principles are explained for Asthi Pradoshaja Vikaras. But in other Samhitas like Sushruta Samhita, Ashtanga Hrudaya, Ashtanga Sangraha the direct reference for the treatment of Asthi Pradoshaja Vikaras. is not available, but treatment principles explained for Asthi Kshaya and Vruddi looks similar as explained in Charaka Samhita. The treatment modalities are Panchakarama (Tikta Ksheera Sarpi Basti) and Vatahara Ahara-Vihara.

\section{Panchakarma}

This is the major treatment modality, which is always used to eradicate the diseases which are located in Shaakha, Marma, Asthisandhi and this is is the best treatment for chronic disorders. By adopting Panchakarma one can subside the Doshas which are located all over the body and by this diseases can be eradicated completely. Ability of evacuation, superiority and enormity of the procedures, target of Dosha eradication and multitude of action are characteristics of Panchakarma. Bones are present all over the body and are the hardest structures in the body. Due to these reasons Panchakarma is the major procedure for Asthi Pradoshaja Vikara.

\section{Basti}

Basti is the best treatment modality for Vata and the vitiated Doshas located below the Nabhi Pradesha. The administered Basti reaches the Pakvashaya which is the place of Purishadhara Kala. Pakvashaya and Asthi are the main seats of Vata Dosha, therefore increased or decreased formation of Vata affects all the sites of Vata especially Asthi. Hence Purishadhara Kala is also considered Asthidhara Kala. So it invariably nourishes the Asthi also.

Especially tikta sadhita ksheera sarpi basti is indicated in Asthi Pradoshaja Vikaras. Tikta Rasa has predomonently Vayu and Akasha Mahabhuta and as per Arunadatta Tikta Rasa has a unique property to maintain the Kharatva of Asthidhatu. Asthi also has preodominently Pruthvi, Vayu and Teja Mahabhuta. So Tikta invariably increases the Kharatva in the Asthi. Ksheera and Sarpi has predominantly Pruthvi, Jala Mahabhuta and Madhura Rasa yukta. These properties will check the vitiated Vata Dosha. The provocation of Vata will result into Asthi Dhatu Dushti. Basti is the best treatment explained for Vata Dosha so the Tikta Rasa in combination with Sneha Dravyas in the form of Basti have a bifold nature i.e it provides sufficient nourishment to the Asthi Dhatu as well as check the Vata Dosha also.

Among the Asthi Pradoshaja Vikara Adhidanta, Dantabheda, Dantashoola, Krimidanta, Indralupta, Khalitya and Palitya occurs in the Jatruurdhva Pradesha. So Nasya, Kavala, Gandusha, Shiroabhyanga are considered to be the main treatment modalities. Asthishoola, Asthibheda, Asthitoda and Adhyasthi are may manifest anywhere in the body, so Basti is considered as main treatment principle.

\begin{tabular}{|c|c|c|c|}
\hline \multirow[b]{2}{*}{ Asthipradoshajavikaras } & \multicolumn{3}{|c|}{ Chikitsa } \\
\hline & Panchakarma & Shastra Karma & Shamana Karma \\
\hline Adhidanta & $\begin{array}{l}\text { Raktamokshana, } \\
\text { Nasya }\end{array}$ & $\begin{array}{c}\text { Kshara karma, Agni karma, } \\
\text { Dantanirharana }\end{array}$ & Gandusha \\
\hline Dantabheda & Vasti & - & $\begin{array}{c}\text { Kavala } \\
\text { Gandusha } \\
\text { Abhyanga } \\
\text { Swedana }\end{array}$ \\
\hline Dantashoola & Nasya & $\begin{array}{l}\text { Dantanirharana } \\
\text { Dantapalilekhana }\end{array}$ & $\begin{array}{c}\text { Gandusha } \\
\text { Pratisarana } \\
\text { Kavala }\end{array}$ \\
\hline Krimidanta & $\begin{array}{l}\text { Raktamokshana } \\
\text { Avapeedanasya }\end{array}$ & $\begin{array}{l}\text { Dantanirharana } \\
\text { Agni karma }\end{array}$ & $\begin{array}{l}\text { Gandusha } \\
\text { Lepa }\end{array}$ \\
\hline Indralupta & Raktamokshana & Siravyadha & $\begin{array}{c}\text { Lepa } \\
\text { Shiroabhyanga }\end{array}$ \\
\hline
\end{tabular}




\begin{tabular}{|c|c|c|c|}
\hline Khalitya\&Palitya & Nasya & - & $\begin{array}{c}\text { Shiroabhyanga } \\
\text { Lepa }\end{array}$ \\
\hline $\begin{array}{c}\text { Adhyasthi, } \\
\text { Asthishoola } \\
\begin{array}{c}\text { Asthibheda } \\
\text { Asthitoda }\end{array}\end{array}$ & Basti & - & $\begin{array}{c}\text { Abhyanga } \\
\text { Swedana }\end{array}$ \\
\hline
\end{tabular}

\section{Conclusion}

- Asthi Pradoshaja Vikara is a condition in which Asthi gets vitiated extremely by the Vata Dosha and changes its natural form and leads to many disorders.

- Ativyayama, Atisankshobha, Ativighattana and Vatala Ahara-vihara are the four Nidanas for Asthi Pradoshaja Vikara.

- Avyakta or Alpavyakta Lakshanas of Asthi Pradoshaja Vikara are considered as Poorvarupa.

- Asthi Pradoshaja Vikara are classified into various types based on the involvement of Asthi, Danta, Kesha and Nakha.

- As Asthi Pradoshaja Vikara are Marmasthigata Vyadhis, so Panchakarma is the best choice of treatment.

\section{Conflict of Interest: None}

\section{References}

1. Acharya YT, Acharya NR. Sushruta Samhita of Sushruta, Varanasi. Chaukhamba Surabharati Prakashan, Reprinted 2008; 115.

2. Acharya YT, Acharya NR. Sushruta Samhita of Sushruta, Varanasi. Chaukhamba Surabharati Prakashan, Reprinted 2008; 116.

3. Acharya YT. Charaka Samhita of Agnivesha, $5^{\text {th }}$ Edition, Varanasi, Chaukhambha Prakashan. 2007; 179.

4. Acharya YT, Acharya NR. Sushruta Samhita of Sushruta, Varanasi. Chaukhamba Surabharati Prakashan. Reprinted 2008; 116.

5. Sen YN. Charaka Samhita of Charaka, $2^{\text {nd }}$ Vol, Banaras, Chaukhamba Sanskrit Series Office. 1922; 988.

6. Acharya YT. Charaka Samhita of Agnivesha, $5^{\text {th }}$ Edition, Varanasi, Chaukhambha Prakashan. 2007; 252.

7. Acharya YT. Charaka Samhita of Agnivesha, $5^{\text {th }}$ Edition, Varanasi, Chaukhambha Prakashan. 2007; 179.

8. Vaidhya Harishastri Paradakara, Ashtanga Hrudaya of Vagbhata, $9^{\text {th }}$ Edition, Varanasi, Chaukhambha Orientalia, 2009; 846.

9. Vaidhya Harishatri Paradakara, Ashtanga Hrudaya of Vagbhata, $9^{\text {th }}$ Edition, Varanasi, Chaukhambha Orientalia, 2009; 846.

10. Acharya YT, Acharya NR. Sushruta Samhita of Sushruta, Varanasi, Chaukhamba Surabharati Prakashan, Reprinted 2008; 332.

11. Acharya YT, Acharya NR. Sushruta Samhita of Sushruta, Varanasi, Chaukhamba Surabharati Prakashan,
Reprinted. 2008; 332.

12. Vaidhya Harishastri Paradakara, Ashtanga Hrudaya of Vagbhata, $9^{\text {th }}$ Edition, Varanasi, Chaukhambha Orientalia. 2009; 846.

13. Vaidhya Harishastri Paradakara, Ashtanga Hrudaya of Vagbhata, $9^{\text {th }}$ Edition, Varanasi, Chaukhambha Orientalia. 2009; 201.

14. Yadunandana Upadhyaya, Madava Nidana Vol 1, Varanasi, Chaukhambha Sanskrit Sansthan. 2003; 513.

15. Vaidhya Harishastri Paradakara, Ashtanga Hrudaya of Vagbhata, $9^{\text {th }}$ Edition, Varanasi, Chaukhambha Orientalia, 2009; 201.

16. Acharya YT, Acharya NR. Sushruta Samhita of Sushruta, Varanasi, Chaukhamba Surabharati Prakashan, Reprinted. 2008; 320.

17. Vaidhya Harishastri Paradakara, Ashtanga Hrudaya of Vagbhata, $9^{\text {th }}$ Edition, Varanasi, Chaukhambha Orientalia. 2009; 889.

18. Acharya YT. Charaka Samhita of Agnivesha, $5^{\text {th }}$ Edition, Varanasi, Chaukhambha Prakashan. 2007; 180. 